\title{
INHIBITION OF CHOLESTEROL BIOSYNTHESIS BY TRIPARANOL IN RHEUMATOID ARTHRITIS
}

\author{
BY
}

\author{
J. L. KALLIOMÄKI, H. A. SAARIMAA, AND P. O. SEPPÄLÄ \\ From the Department of Medicine, University of Turku, Finland
}

Triparanol ( $\beta$-L-diethylaminoethoxyphenyl-1-[- $p$ tolyl]-2-p-chlorophenyl)* is an efficient inhibitor of endogenous cholesterol biosynthesis (Blohm and MacKenzie, 1959). It seems to prevent the conversion of 24-dehydrocholesterol (desmotserol) to cholesterol (Avigan, Steinberg, Thompson, and Mosettig, 1960; Frantz, Mobberley, and Schroepfer, 1960). Recently, it has been shown that triparanol, in doses of $1,000 \mathrm{mg}$. per day, significantly reduces the production of cortisol and aldosterone in healthy subjects and in patients with hyperadrenalism (Melby, St. Cyr, and Dale, 1961).

The aim of this investigation was to study the effect of this possible partial inhibition of adrenalsteroid hormone production induced by triparanol in patients with rheumatoid arthritis.

\section{Material}

Our series consisted of ten female patients with rheumatoid arthritis. Their average age was 52.9 years (range 33 to 67). In seven cases, the length of rheumatoid history was over 5 years, in two cases 2 to 3 years and in one case 2 months. In eight cases the disease was in a highly active phase, and in two it was inactive. None had received any adrenal-steroid therapy during the year preceding this test.

* G.M.C. Approved Name, 1962: 2-p-Chlorophenyl-1-(p-diethylaminoethoxyphenyl)-1-p-Volylethanol.

\section{Method}

The patients were hospitalized during the whole period of the test. Triparanol was administered in daily doses of $750 \mathrm{mg}$. for 15 days, after a control period of at least 3 days.

The 24-hr urine was collected on two consecutive days, once before Triparanol treatment was started, and twice during the treatment period (on the 5th-7th days and on the 14th-15th days). All samples were analysed for total 17-hydroxycorticosteroids (17-OHCS) and those from six patients for 17-ketosteroids (17-KS) also.

On the same test days single determinations of the erythrocyte sedimentation rate, blood haemoglobin, blood total leucocytes and eosinophils, blood sugar, and serum sodium and potassium were performed.

The serum cholesterol was determined before triparanol treatment was started, and again on the 15th day of treatment.

During the whole experimental period, objective and subjective evaluation of joint tenderness and pain, duration of morning stiffness, and demand for analgesics were recorded daily.

\section{Results}

Biological Findings.-These are shown in the Table. The erythrocyte sedimentation rate decreased significantly during the test period $(P<0.05)$, and the blood eosinophils showed a tendency to rise

TABLE

AVERAGE BIOLOGICAL CHANGES DURING 2 WEEKS' TREATMENT WITH TRIPARANOL OF TEN FEMALE PATIENTS WITH RHEUMATOID ARTHRITIS

\begin{tabular}{|c|c|c|c|c|c|c|c|c|c|c|}
\hline \multirow[b]{2}{*}{ Time of Test } & \multicolumn{4}{|c|}{ Blood } & & \multicolumn{3}{|c|}{ Serum } & \multicolumn{2}{|c|}{ Urine } \\
\hline & $\begin{array}{c}\text { E.S.R. } \\
(\mathrm{mm} . / \mathrm{hr})\end{array}$ & $\begin{array}{c}\text { Hb } \\
\text { (g. } \\
\text { per cent.) }\end{array}$ & $\begin{array}{l}\text { Eosino- } \\
\text { phils } \\
\text { (c.mm.) }\end{array}$ & $\begin{array}{c}\text { Leuco- } \\
\text { cytes } \\
\text { (c.mm.) }\end{array}$ & $\begin{array}{l}\text { Sugar } \\
\text { (mg. } \\
\text { per cent.) }\end{array}$ & $\begin{array}{c}\mathrm{Na} \\
(\mathrm{mEq})\end{array}$ & $\begin{array}{c}\mathrm{K} \\
(\mathrm{mEq})\end{array}$ & $\begin{array}{c}\text { Chol- } \\
\text { esterol } \\
\text { (mg. } \\
\text { per cent.) }\end{array}$ & $\begin{array}{c}\text { 17-OHC S } \\
\text { (mg./ } \\
24 \mathrm{hrs})\end{array}$ & $\begin{array}{c}\text { 17-KS } \\
\text { (mg./ } \\
24 \mathrm{hrs})\end{array}$ \\
\hline Before Treatment .. & 55 & $12 \cdot 4$ & 125 & 9,290 & 103 & 139 & $4 \cdot 2$ & 311 & $5 \cdot 3$ & $6 \cdot 7$ \\
\hline$\overline{6 \text { th- }-7 \text { th day of Treatment } . .}$ & 44 & $12 \cdot 6$ & 154 & 9,000 & 108 & 141 & $4 \cdot 2$ & - & $5 \cdot 8$ & $5 \cdot 3$ \\
\hline $14 \mathrm{th}-15 \mathrm{th}$ day of Treatment & 39 & $12 \cdot 7$ & 167 & 6,840 & 95 & 140 & $4 \cdot 5$ & 253 & $6 \cdot 4$ & $4 \cdot 1$ \\
\hline
\end{tabular}


(not statistically significant). The changes in haemoglobin, total blood leucocytes, blood sugar, and serum sodium and potassium were not significant; for example, the average increase in serum potassium, expressed as a percentage of the starting value, was $6.3 \pm 3.13$ per cent. The average decrease in serum cholesterol, however, was significant at the 5 per cent. level.

The changes in total 17-OHCS were not significant, but the average decrease in 17-KS during the triparanol treatment, expressed as a percentage of the control values, was $30 \pm 5.3$ per cent., which is a significant difference $(P<0 \cdot 01)$.

Joint Symptoms. - In the eight cases in which the disease was in the active phase, the joint symptoms became worse in six and no change was observed in two. The triparanol had no effect on the joint symptoms in the two cases in which the disease was initially inactive.

\section{Discussion}

We did not observe the decrease in 17-OHCS so clearly demonstrated in the study of Melby and others (1961). It should be noted, however, that their subjects were all healthy men, and ours were all rheumatoid arthritic women. In a previous study, we showed that the basal urinary excretion of total 17-OHCS and the adrenocortical response to depot ACTH stimulation is significantly more marked in males than in females with rheumatoid arthritis (Pekkarinen and Kalliomäki, 1958).

The decrease in 17-KS in our series during triparanol treatment was exactly the same (30 per cent.) as that observed by Melby and others (1961). It is possible that the endogenous synthesis of androgenic steroids would be more constantly vulnerable to inhibition of cholesterol synthesis by triparanol than is cortisol synthesis (assessed from this point of view, triparanol might be a valuable aid in the treatment of the adrenogenital syndrome).

It was interesting to observe that in many cases the joint symptoms became worse during triparanol treatment despite the amelioration of some of the systemic signs of inflammation (E.S.R., Hb, leucocyte count). This is, we believe, evidence of the role of the endocrinal function in some symptoms of rheumatoid arthritis, especially pain, joint tenderness, and morning stiffness. In this connexion it should be remembered that the morning rise in the plasma 17-OHCS may be reduced in rheumatoid arthritics (according to Ward, Wu, Hench, Mason, Slocumb, Polley, and Mayne: see Duff, 1956), and that premenstrual aggravation of joint symptoms was reported by 41 per cent. of a series of female rheumatoid arthritics (Kalliomäki and Rauramo, 1960). In the present series, however, only the $17-\mathrm{KS}$ were affected by the administration of triparanol.

\section{Summary}

(1) Triparanol, an inhibitor of cholesterol biosynthesis, administered in doses of $750 \mathrm{mg}$. per day, reduced the urinary excretion of 17-ketosteroids, but had no effect on that of 17-hydroxycorticosteroids in ten female rheumatoid arthritics.

(2) In six of eight female patients with rheumatoid arthritis in the active phase, the joint symptoms became worse during treatment with triparanol, despite the amelioration of some of the systemic signs of inflammation.

(3) The serum cholesterol decreased significantly during triparanol treatment. Changes in serum sodium and potassium and in blood sugar and blood eosinophils were not significant.

\section{REFERENCES}

Avigan, J., Steinberg, D., Thompson, M. J., and Mosettig, E. (1960). Progr. cardiovasc. Dis., 2, 525 .

Blohm, T. R., and MacKenzie, R. D. (1959). Arch. Biochem., 85, 245.

Duff, I. F. (1956). Bull. rheum. Dis., 7, 115.

Frantz, I. D., Jr., Mobberley, M. L., and Schroepfer, G. J. (1960). Progr. cardiovasc. Dis., 2, 511.

Kalliomäki, J. L., and Rauramo, L. (1960). Acta endocrincl. (Kbh.), 34, 45.

Melby, J. C., St. Cyr, M., and Dale, S. L. (1961). New Engl. J. Med., 264, 583.

Pekkarinen, A., and Kalliomäki, L. (1958). Acta endocrinol. (Kbh.), 28, 417.

Inhibition de la biosynthèse du cholestérol par le triparanol dans l'arthrite rhumatismale

\section{RÉSUMÉ}

(1) Le triparanol, inhibiteur de la biosynthèse du cholestérol, administré en doses de $750 \mathrm{mg}$. par jour, réduisait l'excrétion urinaire des 17-cétostéroides, mais n'exerçait pas d'effet pareil sur les 17-hydroxycorticostéroides chez dix femmes atteintes d'arthıite rhumatismale.

(2) Chez six sur huit femmes atteintes d'arthrite rhumatismale à la phase active, les symptômes articulaires se sont aggravés pendant le traitement par le triparanol, malgré l'amélioration de certains signes généraux d'inflammation.

(3) Le cholestérol sérique baissait appréciablement pendant le troitement au triparanol. Les altérations du sodium et potassium sérique et de la glycémie, ainsi que celles de l'éosinophilie, n'étaient pas appréciables. 
Inhibición de la biosíntesis del colesterol por el triparanol en la artritis reumatoide

\section{SUMARIO}

(1) El triparanol, un inhibidor de la biosíntesis del colesterol, administrado en dosis de $750 \mathrm{mg}$. diarios, redujo la excreción urinaria de los 17-cetosteroides, pero no tuvo tal efecto sobre los 17-hidroxicorticosteroides en diez mujeres con artritis reumatoide.
(2) En seis de ocho mujeres enfermas con artritis reumatoide en la fase activa, los síntomas articulares empeoraron durante el tratamiento por triparanol, a pesar de la mejoría de algunos de los signos generales de inflamación.

(3) El colesterol sérico disminuyó apreciablemente durante el tratamineto por triparanol. Alteraciones en el sodio y potasio séricos y el azucar en sangre, así como $\underline{\bar{E}}$ en los eosinófilos no fueron significativas. 